\section{INTEREST DF LATVIAN AND \\ LITHUANIAN STUDENTS IN SCIENCE AND MATHEMATICS}

\section{Dagnija Cēdere, Inese Jurgena, Vilija Targamadze}

\section{Introduction}

The science and technology education is closely connected with the society's development; however, many international and national studies reveal the contradiction between the increasing societal needs and the insufficient level of young people's education in this field (Birzina, Cedere, 2017; OECD, 2016).

Interest is one of the components of intrinsic motivation and one of the reasons why students may enjoy learning. What distinguishes it from other sources of enjoyment is that interest is always directed towards an object, activity, a field of knowledge or goal (OECD, 2016). Interest is a strong motivator, the emotional stress which helps indirectly the memory processes and makes the learning considerably easier. Interest is caused both by what has been recognized in the experience and the new, what does not yet exist in the newly developed experience. Thus, the source of interest is both the surrounding environment and the learner's own experience (Žogla, 2001, p. 179). Student's interest in learning or the cognitive interest is one of the most important creators of the learning motivation that influences students' engagement and achievement in learning (Schiefele, 1991). Interest-triggered learning activities lead to a higher degree of deep learning (Krapp, Prenzel, 2011; Osborne, Simon, \& Collins, 2003; Uitto, Juuti, Lavonen, \& Meisalo, 2008). The cognitive interest plays a key role in influencing the students' learning behaviour and their intention to participate in building their future. It is characterized by their learning motive (why students learn) and the teaching/learning strategy (how they learn). It represents a specific relationship between the developing personality and some content of his/her life-space (Aikenhead, 2005).

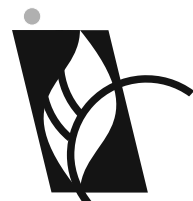

J O U R A L

$\mathrm{OF} \bullet \mathrm{B}$ A L T I C

$S$ C I E N C E

EDUCATION

ISSN 1648-3898 /Print/ ISSN 2538-7138 /Online/

Abstract. Interest is one of the most important components for a successful teaching/ learning process; unfortunately, nowadays students' interest in science and mathematics is decreasing. The aim of the research is to explore the cognitive interest of 15-yearold students in science and mathematics. Students in Latvia and Lithuania participated in the survey; the data show that students' cognitive interest in this area in both countries is mediocre. The factor analysis was used to single out four main dimensions of the cognitive interest - interest in the context, interest in mathematics, inquiry interest and enthusiasm. Students' interest is higher in issues connected with practical life, the solution of real problems, but much lower if the problem to be solved needs effort, if they have to use mathematical tools. Enthusiasm is not characteristic for students. Only few respondents are willing to engage in science and mathematics in their leisure time. Latvian and Lithuanian students show slight differences in their interests. There are more Lithuanian students, who like mathematics and who are not afraid of difficulties. Latvian students, in their turn, show greater enthusiasm.

Keywords: cognitive interest, science and mathematics, teaching/learning process.

Dagnija Cēdere, Inese Jurgena University of Latvia, Latvia Vilija Targamadze Vilnius University, Lithuania 


\section{Problem of Research}

The degree to which students' interest in science and mathematics has been roused at school exerts the most direct impact on their further studies in the higher education institution. Despite the teachers' attempts to increase the young people's interest, the science and technology studies, unfortunately, lack the popularity (Birzina \& Cedere, 2017; Osborne, Simon, \& Collins, 2003).

The lack of interest in science is an old issue and it still exists (Cedere, Gedrovics, Bilek, \& Mozeika, 2014; Potvin \& Hasni, 2014). As mentioned by J. Osborne (2014), science education often fails to attain the intended goals because students lack interest in the science subjects. The interest in mathematics has been comparatively less studied; however, the close connection between the science teaching/learning process and mathematics indicates a similar trend, which is proved also by PISA (The Programme for International Student Assessment) studies (PISA, 2015).

The research findings emphasize that the formation of interest is a complex process; it can change depending on students' age and the teaching/learning environment. Usually the interest in basic school is higher and it gradually decreases in the secondary school. Although the cognitive interest is one of the most significant learning incentives, the relation between the student's cognitive interest and the learning progress cannot be valued unambiguously (Osborne 2014; Krapp \& Prenzel, 2011).

\section{Research Focus}

Nowadays the strategy of science and mathematics education envisages a close unity between the theory and practice, trying to ensure students' active and meaningful participation in the teaching/learning process. The conceptual solutions meant for improving the quality of education are mainly grounded on the context-based learning (Broman, Bernholt, \& Parchmann, 2015), the inquiry-based learning approach (Graeber, 2012), argumentation and decision-making skills (Osborne, 2014; Mörk, 2005). If sciences are taught so that students understand the immediate connection of knowledge with the real life situations in which they are personally interested, then there is a hope that their interest in sciences will remain stable or even will increase (Pilot, Taconis, \& den Brok, 2016). The teaching/learning strategies in mathematics have a similar orientation (France, 2010).

The concept of interest is used in different ways in the literature on science education. The concepts of situational interest and individual interest (stable interest), which are frequently used in pedagogical studies (Krapp \& Prenzel, 2011; Elster, 2007) are used to assess the depth and stability of the interest. Besides, in science interest is treated in accordance with the guidelines and aim of the learning process. A model to explore the students'interests in physics is developed according to this principle (Haeussler \& Hoffmann, 2000). This model distinguishes three dimensions of the interest: 1 ) interest in the concrete topic of physics (content); 2 ) interest in the concrete context in which the topic of physics is presented; and 3) interest in the concrete activity in which the student can engage in relation to this topic. The bi-dimensional interest model, which singles out two areas of interest - interest in the content and interest in the context (Elster, 2007), is also used in science.

Students' learning activity and learning motivation has become the determinative guiding motive in education in Latvia and Lithuania during the last 15 years. The main school subjects of the STEM area that the 15-year old students of Latvia and Lithuania acquire are the science subjects - biology, chemistry and physics as well as mathematics.

Seeing the essence and values of science subjects and mathematics for the future life promotes the contextbased and inquiry-based approach in learning. Both approaches help students to gain a deeper and broader understanding about what we know and how we know it. The inquiry-based learning provides a more authentic idea about what sciences are and how they function (Kalnina, 2008; Lamanauskas, 2012).

However, the research shows that students not always achieve the desired outcome in the science subjects and mathematics. It was found out in the comparative research of Latvian and Lithuanian students that was performed more than ten years ago (Lamanauskas, Gedrovics, \& Raipulis, 2004) that students' science knowledge in the countries worsened. The youth perceive nature mainly in a utilitarian way giving preference to such science issues that demand less effort. Students' activities in nature are mainly connected with recreation, including sports, fishing, hiking but students' various observations in nature are less popular. According to OECD PISA 2015 data in Latvia and Lithuania in comparison with mean indicator of the OECD participant countries, there is approximately a twice smaller number of those students whose achievement corresponds to a high achievement level (PISA 2015). Another study performed at the same time in Latvia obtained a similar result in relation to the cognitive interest, 
namely, only the fifth part of Grade 9 (15-years old) students showed a high level of cognitive interest in science subjects and mathematics (Cedere, Jurgena, Helmane, Tiltina-Kapele, \& Praulīte, 2015). These facts indicate that achievement in learning is closely connected with the cognitive interest.

Our intention in this research was to find out how 15-year old students in Latvia and Lithuania evaluate their interest in science. As the education strategies regarding the science subjects in the countries actually do not differ (Science Education in Europe, 2011), the results are comparable. Additionally, the authors wanted to single out the main fields of interest in order to gain a better understanding about the mutual correspondence between the teaching/learning process and students' interests.

The following research questions were put forward:

- Do 15-year-old students learn science subjects (biology, chemistry, and physics) and mathematics with interest in Latvia and Lithuania?

- Which are the main features that characterize students' cognitive interest about science subjects and mathematics?

- Is there a difference between the 15-year-old students' cognitive interest in science and mathematics in Latvia and Lithuania?

\section{Methodology of Research}

\section{General Characteristics}

This research was carried out in the period from 2015 to 2017 in Latvia (LV) and Lithuania (LT). A students' survey that describes their cognitive interest in science and mathematics was used in the research. Students participated in the survey based on volunteering principle. Data were collected from different basic and secondary schools in different regions of Latvia and Lithuania.

The key guidelines of science (biology, chemistry and physics) and mathematics education and strategies for solving the problems do not differ significantly in Latvia and Lithuania (Mathematics Education in Europe, 2011; Science Education in Europe, 2011). Mathematics in both countries as a separate subject is taught already from Grade 1 (4-6 lessons a week), biology, chemistry and physics as separate subjects - from Grade 7 or 8 (each subject is taught 2 lessons a week). These subjects as compulsory are included in the national curricula of both countries (BUP 20152017 keitimas; Izvērsta informācija par izglītības programmām).

\section{Sample}

The total number of students involved in the research was 990, of them - 536 (54\%) were from Latvia and 454 (46\%) from Lithuania. Students of the same age from both countries who learn in Grade 9 in both countries) or the first year at the gymnasium (only in Lithuania) participated in the survey. The average age of the respondents was 15.1 years $(S D=0.59)$. The distribution of respondents by gender $-572(58 \%)$ girls and $418(42 \%)$ boys. The distribution per country - distribution by gender in Latvia - 328 (61\%) girls and 208 (39\%) boys; in Lithuania - 244 (54\%) girls and 210 (46\%) boys.

\section{Instrument and Procedures}

The survey used the questionnaire which included questions, how students evaluate their cognitive interest in science and mathematics (Part A, 14 items), which the main themes of interest are (Part B, 16 items) and what is the attitude to science and mathematics lessons (Part C, 4 items). Content-wise the questionnaire corresponds to the skills and attitudes that are mastered at school in biology, chemistry, physics and mathematics. The survey focussed on students' awareness of the importance of knowledge and skills in science and mathematics in the real life and their readiness to act. The questionnaire comprised questions where the answer options corresponded to the four-value Likert scale: 1 - no, 4 - yes (Schreiner, Sjøberg, 2004).

The questionnaire that had been applied previously in the research of the cognitive interest of a small students' sample in Latvia (Cedere, Jurgena, Helmane, Tiltina-Kapele, \& Praulīte, 2015). The participation of the students from two neighbouring countries has broadened the range of respondents in this research. It opens the possibility for a more profound study of the students' cognitive interest gaining more general and substantiated indicators 
showing the tendency of the cognitive interest. The questionnaire was prepared on the internet using the Google disc; students answered questions online. A link was announced to teachers who had agreed to participate in the organization of the study.

The reliability (inter-item consistency) of the questionnaire according to Cronbach's alpha coefficient was 0.91.

\section{Data Analysis}

The mean values of answers $M(1 \leq M \leq 4)$ and standard deviations (SD) were used to describe the respondents' opinions. In order to assess the credibility of the differences of mean values in two reciprocally independent groups, the t test analysis of the independent samples was used. To describe the differences of the distribution of respondents' answers in two different groups, Pearson Chi Square test was applied. Cohen's d was calculated for estimating the effect size for the difference between two means.

The factor analysis allowed grouping the information from a large number of features into a few factors, thus obtaining a more obvious information about the students' interests. Principal component analysis (PCA) with varimax rotation was applied. The Kaiser-Meyer-Olkin (KMO) measure of sampling adequacy tests and Bartlett's tests for sphericity were used in order to find if the PCA was appropriate for these data sets. In order to determine the correct number of factors that had to be preserved in the PCA analysis, the parallel analysis was applied (Hayton, Allen, Scarpello, 2004; Watson, 2017).

Cronbach's alpha coefficients were calculated for stating the reliability of the questionnaire and the reliability of extracted principal components.

One sample Kolmogorov-Smirnov test was applied to determine if the distribution showed a normal distribution before the analysis. It was determined that all the distributions showed normal distribution $(p<.001)$.

The data analysis was performed using the statistical software SPSS 23 program.

\section{Results of the Research}

\section{Students' Attitude to Science and Mathematics Lessons}

Students' answers to the question Do you think with pleasure about the biology/chemistry/physics/mathematics lessons? provided a general idea about the Latvian and Lithuanian 15-year old students' attitude to science and mathematics. The mean values of the answers $M(1 \leq M \leq 4)$ are only just a little above the average quantity of the scale 2.5 that indicates an average liking to these subjects (Table 1 ).

Table 1. Students' liking in learning biology, chemistry, physics and mathematics.

\begin{tabular}{lllll}
\hline \multicolumn{1}{c}{ Items } & $\mathbf{N}$ & $\mathbf{M}$ & SE & SD \\
\hline Biology (C1) & 925 & 2.82 & .032 & 0.962 \\
Mathematics (C4) & 935 & 2.73 & .035 & 1.078 \\
Chemistry (C2) & 933 & 2.51 & .034 & 1.038 \\
Physics (C3) & 932 & 2.47 & .034 & 1.041 \\
\hline
\end{tabular}

The questions were answered positively (yes and rather yes) about biology by $29 \%$ and $35 \%$, about chemistry by $22 \%$ and $26 \%$, about physics by $20 \%$ and $29 \%$, about mathematics by $31 \%$ and $30 \%$ of respondents.

\section{Principal Component Analysis}

The factor analysis was applied to find out the most important features of the science interest. This was the way to search for reciprocally non-correlating items, reducing the number of factors characterising respondents' cognitive interest. Questionnaires Part A and Part B were used for factor analysis.

First, the appropriateness of data for performing the factor analysis was found out. The KMO and Bartlett's tests helped to prove that the data were meaningful and compatible to perform the factor analysis. The KMO measure of sampling adequacy was 0.91 and Bartlett's test of sphericity was significant $\left(c^{2}(496)=4637.10, p<.001\right)$. 
The principal component analysis (PCA) was performed using the extraction method with the succeeding rotation of varimax with Kaiser normalization. Items with the factor loading no less than 0.40 were subjected to the analysis. A critical decision in exploratory factor analysis is to determine how many principal components to retain. The parallel analysis (PA) was used for this purpose (Figure 1). As seen in Figure 1, four of the eigenvalues of the real data are greater than the average eigenvalues of the PA mean.

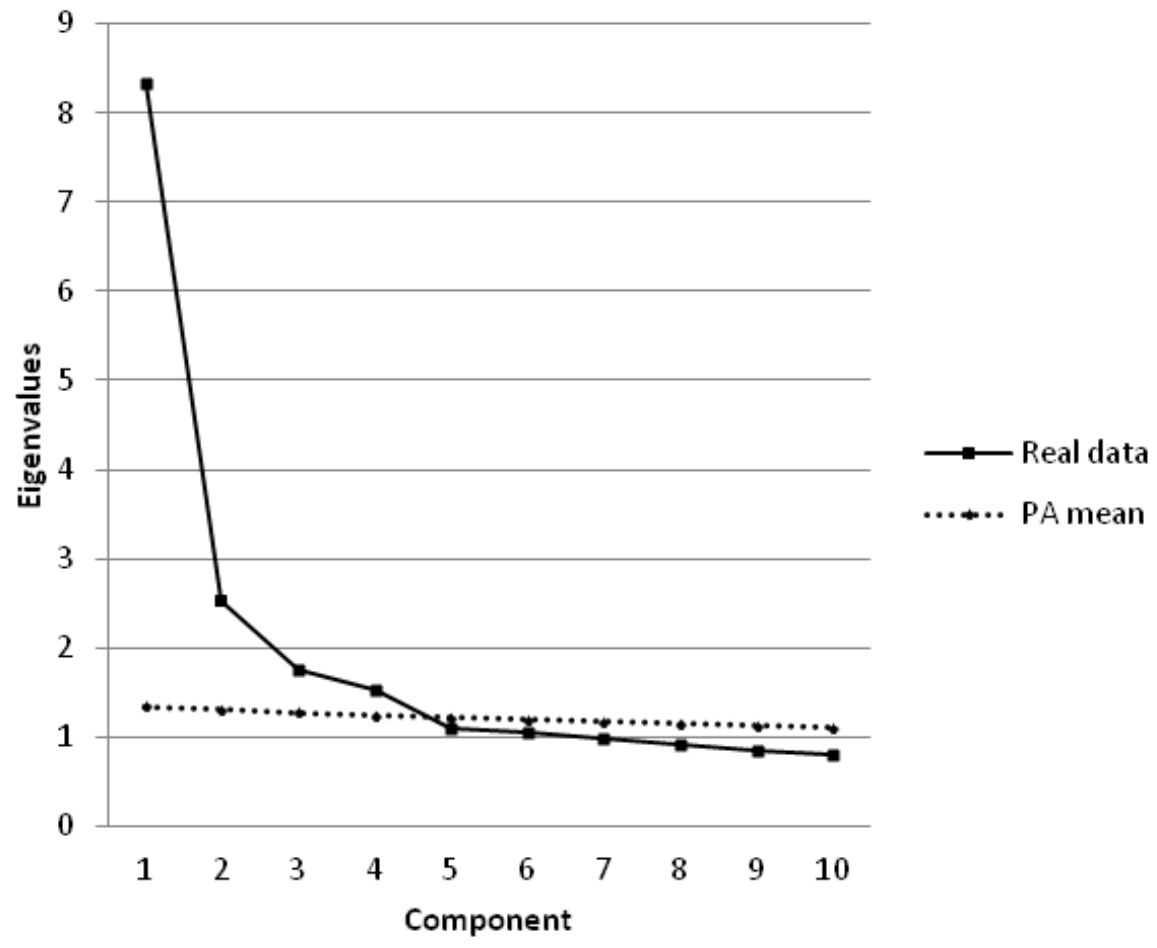

Figure 1: Plot of real data (PCA) and randomly generated eigenvalues (PA).

The parallel analysis indicates that four components or factors should be retained which explain $47 \%$ of the variance and do not correlate reciprocally. The findings obtained in the PCA are summarized in Table 2; it includes the 17 most important items with the factor loading values above 0.60 . Thus, the factor analysis allowed reducing the initial number of quantities describing the students' interest from 30 to 17 (excluded items see in Appendix). The established factors describe four main dimensions of students' interest and their distribution does not overlap in two or more factors.

Table 2. Results of the principal component analysis with a varimax rotation of items.

\begin{tabular}{|c|c|c|c|c|c|c|}
\hline \multirow{2}{*}{ Items } & \multirow{2}{*}{ M } & \multirow{2}{*}{ SD } & \multicolumn{4}{|c|}{ Rotated factor load values } \\
\hline & & & Factor 1 & Factor 2 & Factor 3 & Factor 4 \\
\hline B9. Warming of the water in the glass container & 2.89 & 1.17 & .72 & & & \\
\hline B2. Features of the air after the thunderstorm & 3.05 & 1.12 & .72 & & & \\
\hline B8. Features of the soap solution & 2.30 & 1.16 & .71 & & & \\
\hline B3. Growing and reproduction of plants & 2.34 & 1.12 & .68 & & & \\
\hline B10. Purification of the drinking water & 2.90 & 1.15 & 68 & & & \\
\hline B13. The use of maths in solving practical problems & 2.23 & 1.14 & & .74 & & \\
\hline
\end{tabular}




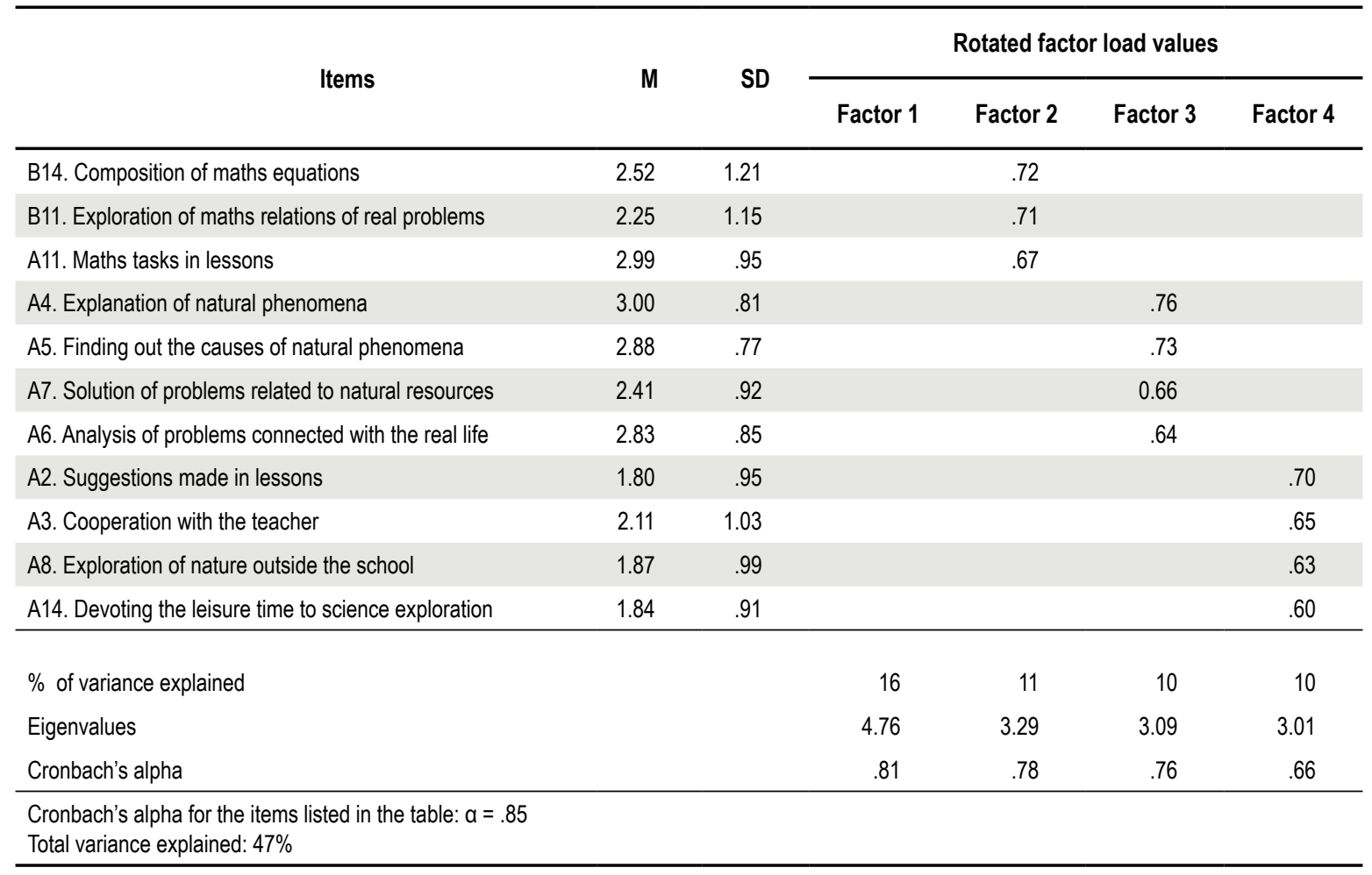

Factor 1 combines the interest related to the nature and practical life, items connected with the solution of complicated tasks and the application of mathematics correspond to factor 2, factor 3 describes the interest to explore and solve real problems and factor 4 reflects students' self-initiative and enthusiasm. The interest dimensions corresponding to obtained factors describe the respondents' interest from the point of view of the teaching/learning content and the process. Thus, the cognitive interest is described by four main features or the dimensions of interest.

\section{Dimensions of the Cognitive Interest}

\section{First dimension. Interest in the context}

Items loading on the dimension, which eigenvalue is 4.76 and Cronbach's $a=0.81$, explained $16 \%$ of variance. This dimension combines the features that characterize students' interest about the everyday life topics, the interest about the structure, features and processes of the surrounding environment /the material world. The items included in this dimension show how important it is to connect the topic of learning to the practical application.

\section{Second dimension. Interest in mathematics}

Items loading on the dimension, which eigenvalue is 3.29 and Cronbach's $a=0.78$, explained $11 \%$ of variance. This dimension shows that students like to compose and solve mathematical tasks in order to solve some real problem in nature or everyday life. They are interested in complex chemistry and physics tasks. They are not afraid of difficulties.

\section{Third dimension. Inquiry interest}

Items loading on the dimension, which eigenvalue is 3.09 and Cronbach's $a=0.76$, explained $10 \%$ of variance.

Students have the interest to solve problems, to analyse and explain the processes in nature and everyday life, to find out their causes. At the same time, this factor includes also students' research skills that students have acquired and are able to apply. 


\section{Fourth dimension. Enthusiasm}

Items loading on the dimension, which eigenvalue is 3.01 and Cronbach's $a=0.66$, explained $10 \%$ of variance. The feature of interest that describes perseverance, the willingness to engage in science also outside the school, the willingness to delve into the process under the exploration and to complete the task. It characterises the depth of the interest.

Comparing the mean values of answers $(\mathrm{M})$ it is seen that students have relatively the highest interest about the contexts (dimension 1) and about the research activity (dimension 3) (Table 2). The mean values of several items in both dimensions are close to the rather agree. The interest about mathematical tasks is much lower (dimension 2). The lowest mean values of answers correspond to the dimension 4, which describes enthusiasm, perseverance, willingness to explore some object or phenomenon outside the school and continue doing until the work is completed.

According to the previously developed scale of the levels of cognitive interest in science and mathematics (Cedere, Jurgena, Helmane, Tiltina-Kapele, \& Praulite, 2015) the interest dimensions 1 - 3 correspond to the average level but the dimension 4 corresponds to a low level.

\section{Comparison of the Cognitive Interest of Latvian and Lithuanian Students}

In order to find out whether there were differences between the interests of Latvian and Lithuanian students, items in each dimension were summed and the $t$ test was performed to compare both independent sets (Table 3 ). To evaluate the effect size of the dimension, Cohen's $d$ was used.

The obtained results show that dimension 2 and dimension 4 have statistically significant interest differences, effect size ( $d=0.32-0.46)$ for both dimensions can be assessed as medium effect (Becker, 2000), which serves as an evidence for the differences in the cognitive interest of students of both countries. Lithuanian students are more interested in mathematics and they compose and solve complex tasks willingly; Latvian students, however, are more enthusiastic and they cooperate more with the teacher. Similar statistically significant interest differences can be seen between girls from both countries and boys in both countries, therefore these differences are not gender-specific (Table 3).

Table 3. Latvian and Lithuanian students' interest in science and mathematics.

\begin{tabular}{|c|c|c|c|c|c|c|c|c|c|c|}
\hline No & Dimension & Respondents & Country & $M$ & SE & SD & $t$ & df & $p$ & $d$ \\
\hline \multirow{6}{*}{1} & \multirow{6}{*}{$\begin{array}{l}\text { Interest in the } \\
\text { context }\end{array}$} & \multirow{2}{*}{ Total } & LV & 26.84 & 0.38 & 7.55 & \multirow{2}{*}{-1.56} & \multirow{2}{*}{738} & \multirow{2}{*}{.12} & \multirow{2}{*}{.11} \\
\hline & & & LT & 27.69 & 0.39 & 7.24 & & & & \\
\hline & & \multirow{2}{*}{ Girls } & LV & 27.36 & 0.46 & 7.25 & \multirow{2}{*}{-2.20} & \multirow{2}{*}{431} & \multirow{2}{*}{.03} & \multirow{2}{*}{.21} \\
\hline & & & LT & 28.89 & 0.54 & 7.04 & & & & \\
\hline & & \multirow{2}{*}{ Boys } & LV & 26.01 & 0.65 & 7.95 & \multirow{2}{*}{-0.26} & \multirow{2}{*}{305} & \multirow{2}{*}{.80} & \multirow{2}{*}{.01} \\
\hline & & & LT & 26.23 & 0.58 & 7.22 & & & & \\
\hline \multirow{6}{*}{2} & \multirow{6}{*}{$\begin{array}{l}\text { Interest in } \\
\text { mathematics }\end{array}$} & \multirow{2}{*}{ Total } & LV & 16.86 & 0.28 & 5.40 & \multirow{2}{*}{-4.37} & \multirow{2}{*}{677} & \multirow{2}{*}{$<.001$} & \multirow{2}{*}{.34} \\
\hline & & & LT & 18.65 & 0.29 & 5.20 & & & & \\
\hline & & \multirow{2}{*}{ Girls } & LV & 16.32 & 0.36 & 5.29 & \multirow{2}{*}{-3.10} & \multirow{2}{*}{385} & \multirow{2}{*}{.002} & \multirow{2}{*}{.32} \\
\hline & & & LT & 17.99 & 0.40 & 5.24 & & & & \\
\hline & & \multirow{2}{*}{ Boys } & LV & 17.67 & 0.45 & 5.47 & \multirow{2}{*}{-2.82} & \multirow{2}{*}{290} & \multirow{2}{*}{.005} & \multirow{2}{*}{.33} \\
\hline & & & LT & 19.41 & 0.42 & 5.07 & & & & \\
\hline & & Total 20 & LV & 13.84 & 0.16 & 3.15 & & & & \\
\hline & & Total & LT & 14.31 & 0.17 & 3.00 & -1.97 & 689 & .06 & .15 \\
\hline 2 & Inouinu intorot & Civt & LV & 13.52 & 0.21 & 3.12 & 221 & 131 & 03 & 10 \\
\hline 3 & Inquiry interest & Girls & LT & 14.07 & 0.21 & 2.73 & -2.21 & 431 & .03 & .19 \\
\hline & & Rove & LV & 14.30 & 0.25 & 3.13 & 076 & 205 & 15 & 00 \\
\hline & & Boys & LT & 14.59 & 0.27 & 3.29 & -0.16 & 295 & .45 & .09 \\
\hline
\end{tabular}




\begin{tabular}{|c|c|c|c|c|c|c|c|c|c|c|}
\hline No & Dimension & Respondents & Country & M & SE & SD & $t$ & df & $p$ & $d$ \\
\hline \multirow{6}{*}{4} & \multirow{6}{*}{ Enthusiasm } & \multirow{2}{*}{ Total } & LV & 13.47 & 0.19 & 3.84 & \multirow{2}{*}{5.92} & \multirow{2}{*}{765} & \multirow{2}{*}{$<.001$} & \multirow{2}{*}{.43} \\
\hline & & & LT & 11.86 & 0.19 & 3.64 & & & & \\
\hline & & \multirow{2}{*}{ Girls } & LV & 13.47 & 0.24 & 3.81 & \multirow{2}{*}{4.73} & \multirow{2}{*}{433} & \multirow{2}{*}{$<.001$} & \multirow{2}{*}{.46} \\
\hline & & & $\mathrm{LT}$ & 11.74 & 0.27 & 3.71 & & & & \\
\hline & & \multirow{2}{*}{ Boys } & LV & 13.47 & 0.31 & 3.90 & \multirow{2}{*}{3.60} & \multirow{2}{*}{330} & \multirow{2}{*}{$<.001$} & \multirow{2}{*}{.40} \\
\hline & & & LT & 11.99 & 0.27 & 3.56 & & & & \\
\hline
\end{tabular}

The distribution of respondents' answers gives a more complete idea about the differences between the students' interests in these countries, therefore the Chi Square test was performed for the selected items. Items with the highest mean factor loading were chosen as examples from dimensions 2 and 4 (Table 4).

Table 4. Differences between the students' interests.

\begin{tabular}{|c|c|c|c|c|c|c|c|c|}
\hline \multirow[b]{2}{*}{ Item } & \multirow[b]{2}{*}{ Country } & \multicolumn{4}{|c|}{ Distribution of respondents' answers, \% } & \multirow[b]{2}{*}{$\chi^{2}$} & \multirow[b]{2}{*}{ df } & \multirow[b]{2}{*}{$\mathrm{p}$} \\
\hline & & No & $\begin{array}{c}\text { Rather } \\
\text { no }\end{array}$ & $\begin{array}{c}\text { Rather } \\
\text { yes }\end{array}$ & Yes & & & \\
\hline \multirow{2}{*}{$\begin{array}{l}\text { The use of mathematics in solving practi- } \\
\text { cal problems (B13) }\end{array}$} & LV & 40.7 & 24.5 & 17.4 & 17.4 & \multirow{2}{*}{12.05} & \multirow{2}{*}{3} & \multirow{2}{*}{.007} \\
\hline & $\mathrm{LT}$ & 30.4 & 25.4 & 21.3 & 23.0 & & & \\
\hline \multirow{2}{*}{ Suggestions made in lessons (A2) } & LV & 40.2 & 36.6 & 14.3 & 8.9 & \multirow{2}{*}{28.36} & \multirow{2}{*}{3} & \multirow{2}{*}{$<.001$} \\
\hline & $\mathrm{LT}$ & 57.1 & 26.6 & 8.5 & 7.8 & & & \\
\hline
\end{tabular}

There is a significant difference between the students' interest in the two countries. The sharpest difference is between the negative answers given by the students. Approximately $40 \%$ of Latvia's students and approx. $30 \%$ of Lithuanian students do not like mathematics at all. In percentage, Lithuanian students have given more affirmative answers. There are also significant differences regarding the enthusiasm and active participation in lessons. In this case, the number of negative answers is similar in both countries but in Latvia there are relatively more students who have answered by rather yes and yes.

\section{Discussion}

A student is motivated to learn if the learning content is connected with the student's interests, his/her experience and if he/she sees that learning prepares him/her for the real life. The present research proves that the interest of the 15-year-old students in science and mathematics on the whole is mediocre although the level of respondents' interest is rather different. The relatively low interest about science that students of this age group have in Latvia and Lithuania has been observed also before (Cedere, Jurgena, Helmane, Tiltina-Kapele, \& Praulīte, 2015; Lamanauskas, Gedrovics, \& Raipulis, 2004).

Evaluating the obtained data on how students assess their interest about learning biology, chemistry, physics and mathematics allows concluding that these school subjects, except biology, do not provoke interest ( $\mathrm{M}=$ 2.32 - 2.77). Students of both countries like learning biology the most (Table 1).

The factor analysis helped to group the quantities characterizing students' interest and single out four features or dimensions of the interest: 1 ) interest in the context, 2) interest in mathematics, 3) inquiry interest and 4) enthusiasm. The first and third dimensions correspond to the main focusses in the strategy of teaching/learning the sciences; the mathematical aspect appears as a separate dimension ( $2^{\text {nd }}$ dimension) which comprises also the solution of complicated tasks in chemistry and physics; the fourth dimension, in its turn, combines students' willingness to find out more, to do more and to explore things with enthusiasm. The evaluation of students'interests according to the dimensions provides valuable information needed for the adjustment of the teaching/learning process.

Interest in the context as a vitally important dimension of interest in science has been applied before (Elster, 2007; Haeussler \& Hoffmann, 2000). The respondents' contextual interest is relatively high in our research (Table 2), besides, there are no significant differences among both countries (Table 3). Thus, it is possible to consider that students are able to see the connection of the teaching/learning content with the real life; furthermore, a poten- 
tial cognitive activity is expected. However, having a closer look at the $4^{\text {th }}$ dimension it is clear that this cognitive interest refers only to the compulsory school classes.

The second significant feature of the science interest - inquiry interest relates to an analogous dimension of the interest that has been used in exploring the interest in physics (Haeussler \& Hoffmann, 2000) although the range of interest included in it is a bit different. This dimension of the interest, too, excels with a relatively high mean value. This serves as an evidence that students have the willingness to research different natural phenomena and they want to engage in the exploration of things that are important in the practical life. If students like exploring, then students are aware of and they are able to apply this type of cognition characteristic to sciences. The inquiry interest is equally high in both countries.

Students' interest in mathematics in the context of the performed survey describes their ability to use mathematics in solving different practical problems, including also calculation tasks in chemistry and physics. This dimension of the interest at the same time characterizes also the formation of connected knowledge and the integration of the school subjects, which is topical in the science acquisition process (Osborne, 2014). The mathematical dimension has not gained great respondents' responsiveness. Respondents assess their interest about the use of mathematics in solving practical problems rather negatively, $M=2.23$ (Table 2). More than a third of respondents have a negative attitude (the answer no) to the solution of real problems if they have to make mathematical equations (Table 4). This allows concluding that many 15 -year- old students do not yet fully understand what sciences are and how they function because sciences cannot do without mathematics. Lithuanian students' interest in mathematics, though, is significantly higher than that of the Latvian students (Table 3).

The fourth dimension of the interest is enthusiasm, which in the respondents' assessment takes the lowest place, indicates the lack of enthusiasm and self-initiative. The mean values of answers show that students are unwilling to devote their free time to science or mathematics, $M=1.84$; they are not interested in the exploration of nature if that is not a compulsory school requirement, $M=1.87$ (Table 2). Approximately $80 \%$ of students have a poorly expressed self-initiative (answers no and rather no) (Table 4). The enthusiasm dimension also includes the willingness to participate in different interest groups and projects that are advisable measures for the formation of the individual science interest (Uitto, Juuti, Lavonen, \& Meisalo, 2006). A low indicator of enthusiasm is characteristic of the respondents in both countries although the mean value of the enthusiasm dimension in Latvia is statistically significantly higher than in Lithuania (Table 3). Enthusiasm is also used in other researches to describe the cognitive interest (Purēns, 2015).

Students' rather high interest in the practical issues and their readiness to engage in their solution can be considered a certain achievement of the education system in Latvia and Lithuania because students have a positive attitude to science and the majority of them have a true understanding of the role of science and mathematics in the real life. However, the present research does not allow stating that students' interest is stable. The negative attitude expressed by any respondents about constructing mathematical equations if the solution of a real problem demands this (Table 4), is indicative of their unwillingness to make an effort. Such a connection has been stated before (Cedere, Jurgena, Helmane, Tiltina-Kapele, \& Praulite, 2015): the interest is higher if the task is formulated simply, it is lower if the formulation of the task requires probing into it. Evasion from overcoming the difficulties as well as the lack of perseverance is a characteristic feature of the modern youth that has also been observed in other subjects (Purēns, 2015).

The comparison of the data from Table 1 and Table 2 (factors 1 and 3) reveals another significant connection - students have interest about science phenomena in the real life, they are interested in acting and exploring themselves, but they quite do not like learning biology, chemistry and physics at school. Thus, students' willingness to explore is greater than the teacher's ability/possibilities to satisfy this willingness. It is possible that one of the reasons is the incongruity between the teaching/learning content and the student.

The student has changed. The $21^{\text {st }}$ century student who is born and lives in the digitalized world is purposeful, but he lacks the patience, the ability to delve in the issue and to keep the attention for a longer period of time that is characteristic of the $20^{\text {th }}$ century student. The breadth and accessibility of the information space has increased the range of cognition and at the same time has changed the way of perception and thinking. Today's generation is oriented towards fast living in today, towards immediate experience. The world is perceived fragmentarily (the so called "clip" thinking), the attention has a short concentration span (Davidova, Sokolova, \& Zarina, 2014). The lack of understanding the connections leads to the situation that today's students do not ask questions about the causes and consequences; they learn that things should be simply accepted without trying to understand their essence (Rowlands, Nicholas, Williams, Huntington, Fieldhouse, Gunter, Withey, Jamali, Dobrowolski, \& Tenopir, 2008). The 
transformed thinking of the youth is connected with the specifics of learning. It would be useful to remember the theory of J. Dewey that emphasizes - one should never forget that human development is promoted only by what he himself has created and developed. A student really gains the necessary experience only when he is engaged in things that he is able to understand and improve. In order to learn something, to widen one's own intellectual outlook students should be able to put the new experience in the context, to be able to add the new impressions to the existing ones (Dewey, 2011).

Transformations are needed in the teaching/learning process so that it corresponds to the modern needs (Hodson, 2014). For the today's students to have a greater interest in learning the science and mathematics, it is necessary to change the approach of teaching, to use the digital technologies more, to apply the corresponding strategies and to strengthen the mutual cooperation with students (Fullan \& Langworthy, 2014). The teaching strategies in science must be focused on understanding the connections and the student's personal experience. The formation of each student's personal interest should be promoted, teaching every student to base his/her science experience not on mutually unrelated, fragmentary knowledge but on analytical, value-judgment thinking.

\section{Conclusions}

The gained findings reflect the attitude of today's youth to science and mathematics. Students who participated in the research on the whole have a mediocre interest about the science subjects and mathematics; besides, there are slight differences between the interests of the Latvian and Lithuanian students.

Students' cognitive interest in science and mathematics is described in the frame of the present research using four dimensions - interest in the context, interest in the mathematics, inquiry interest ad enthusiasm. Students have a relatively high interest about science in the context with the real life and processes in the surrounding environment. Students' inquiry interest is equally high, and it is expressed as making the experiments, analysis, evaluation, finding out the causes, the solution of real life problems. The interest in mathematics that includes also the solution of complicated tasks in chemistry and physics, is relatively low. Approximately a half of the respondents dislike mathematics and they are unwilling to do anything that requires effort. The majority of students lack enthusiasm and perseverance in learning, they have no desire to engage in science or mathematics outside the school.

The most important aspect of the teacher's competence is to find a way how to ensure that students learned with interest and were able to see the usefulness of science and mathematics in their future life. The teaching/ learning process is productive if the student accepts learning as personally meaningful and needed for satisfying one's cognitive interest, for widening one's knowledge, that is useful in interaction with others. As the four found manifesting dimensions of the cognitive interest explain only a half of the total variance, it is possible to conclude that there is a number of other factors that influence the students' interest of learning. The obtained results encourage exploring the distribution of students' answers more closely, thus finding out the reasons for the radically different opinions. This would help teachers find a more suitable approach for the concreate teaching/learning situation.

\section{Acknowledgements}

The authors are greatly thankful to Dr. paed. Ineta Helmane for the participation in the research. The authors also thank all the teachers who were responsive and participated in the organization of the survey.

\section{References}

Aikenhead, G. S. (2005). Research into STS science education. Educación Química, 16 (3), 384-397.

Becker, L. A. (2000). Effect size. Retrieved September 02, 2017, from https://www.uv.es/ friasnav/EffectSizeBecker.pdf.

Birzina, R., \& Cedere, D. (2017). The first year students' perceptions of higher studies: a case of University of Latvia. In V. Dislere (Ed.), Rural environment, education, personality (pp. 40-49). Jelgava: Latvia University of Agriculture. Retrieved September 02, 2017, from http://llufb.Ilu.lv/conference/REEP/2017/Latvia-Univ-Agricult-REEP-2017_proceedings.pdf.

Broman, K., Bernholt, S., \& Parchmann, I. (2015). Analysing task design and students'responses to context-based problems through different analytical frameworks. Research in Science \& Technological Education, 33 (2), 143-161. Retrieved December 2, 2017, from https://www.learntechlib.org/p/168317/.

BUP 20152017 keitimas.docx - Švietimo ir mokslo ministerija [BUP 20152017 Changing.docx - Ministry of Education and Science]. Retrieved November 02, 2017, from http://www.smm.It/uploads/documents/svietimas/BUP\%202015\%202017\%20keitimas. pdf. (In Lithuanian). 
Cedere, D., Gedrovics, J., Bilek, M., \& Mozeika, D. (2014). Changes of 15 years old students' interest in science in Latvia: 2003-2013. In M. Bilek (Ed.), Science and technology education for the 21st century (pp. 103-112). Hradec Králové: Gaudeamus.

Cedere, D., Jurgena, I., Helmane I., Tiltina-Kapele, I., \& Praulìte, G. (2015). Cognitive interest: problems and solutions in the acquisition of science and mathematics in schools of Latvia. Journal of Baltic Science Education, 14 (4), 424-434.

Davidova, J., Sokolova, I., \& Zarina, S. (2014). Peculiarities of personality's self-education in a postmodern society. In E. Aciene (Ed.), Changing education in a changing society (pp. 147-153). Klaipeda: Klaipedos universitetas.

Dewey, J. (2011). Democracy and education. Milton Keynes: Simon and Brown.

Elster, D. (2007). In welchen Kontexten sind naturwissenschaftliche Inhalte für Jugendliche interessant? Plus Lucis, 3, 2-8. Retrieved September 02, 2017, from https://www.univie.ac.at/pluslucis/PlusLucis/073/s2_8.pdf.

France, I. (2010). The research skills in mathematics content for grades 7 to 12, their Implementation into Practice. In Society, Integration, Education (pp. 207-214). Rezekne: Rezekne Higher Education Institution.

Fullan, M., \& Langworthy, M. (2014). A rich seam: How new pedagogies find deep learning. London: Pearson.

Graeber, W. (2012). Reflections on inquiry-based science education in Europe and outlook. In C. Bolte, J. Holbrook, \& F. Rauch (Eds.), Inquiry-based science education in Europe: reflections from the PROFILES project (pp. 221-225). Berlin: Freie Universitat Berlin. Retrieved September 02, 2017, from https://ius.uni-klu.ac.at/misc/profiles/files/Profiles\%20Book\%202012_10.pdf.

Haeussler, P., \& Hoffmann, L. (2000). A curricular frame for physics education: Development, comparison with students' interests, and impact on students' achievement and self-concept. Science Education, 84, 689-705.

Hayton, J. C., Allen, D. G., \& Scarpello, V. (2004). Factor retention decisions in exploratory factor analysis: A tutorial on parallel analysis. Organizational Research Methods, 7 (2), 191-205.

Hodson, D. (2014). Learning science, learning about science, doing science: different goals demand different learning methods. International Journal of Science Education, 36 (15), 2534-2553.

Izvērsta informācija par izglīīibas programmām [Extended information about educational programs]. Retrieved November 02, 2017, from http://ndv.lv/wp-content/uploads/2016/06/lzglitibas_programmas.pdf. (In Latvian).

Kalnina, R. (2008). System for the organization of multilevel independent work aimed at modern mastering of chemistry in vocational education. Journal of Baltic Science Education, 7 (2), 103-121.

Krapp, A., \& Prenzel, M. (2011). Research on interest in science: Theories, methods, and findings. International Journal of Science Education, 33 (1), 27-50. Retrieved September 02, 2017, from http://dx.doi.org/10.1080/09500693.2010.518645.

Lamanauskas, V. (2012). Development of scientific research activity as the basic component of science education. Journal of Baltic Science Education, 11 (3), 200-202.

Lamanauskas, V., Gedrovics, J., \& Raipulis, J. (2004). Senior pupils' views and approach to natural science education in Lithuania and Latvia. Journal of Baltic Science Education, 1 (1), 13-23.

Mathematics Education in Europe (2011). Retrieved November 02, 2017, from eacea.ec.europa.eu/education/eurydice/documents/ thematic_reports/132EN.pdf.

Mörk, S., M. (2005). Argumentation in science lessons: Focusing on the teacher's role. NorDiNa, 1, 17-30.

OECD (2016). PISA 2015 Results (Volume I): Excellence and Equity in Education. Paris: PISA, OECD Publishing. Retrieved September 02, 2017, from http://dx.doi.org/10.1787/9789264266490-en.

Osborne, J. (2014). Teaching Scientific Practices: Meeting the Challenge of Change. International Journal of Science Education, 25 (2), 177-196

Osborne, J., Simon, S., \& Collins, S. (2003). Attitudes towards science: A review of the literature and its implications. International Journal of Science Education, 25 (9), 1049-1079. Retrieved September 02, 2017, from https://doi.org/10.1080/0950069032000032199.

Pilot, A., Taconis, R., \& den Brok, P. J. (2016). Concluding reflections on context-based learning environments in science. In R. Taconis, P. J. den Brok, A. Pilot (Eds.), Teachers creating context-based learning environments in science (pp. 225-242). Rotterdam: Sense Publishers. Retrieved September 02, 2017, from https://link.springer.com/chapter/10.1007/978-94-6300-684-2_13.

PISA 2015. Results in Focus. Retrieved September 02, 2017, from http://www.oecd.org/pisa/pisa-2015-results-in-focus.pdf.

Potvin, P., \& Hasni, A. (2014). Interest, motivation and attitude towards science and technology at K-12 levels: a systematic review of 12 years of educational research. Studies in Science Education, 50 (1), 85-129.

Purēns, V. (2015). Pusaudžu izzinas intereses veidošanās dialoǵiskajā vēstures mācību procesā. Doktora disertācija [Development of adolescent cognitional interest in dialogical history studies. Doctoral Thesis]. (In Latvian)

Rowlands, I., Nicholas, D., Williams, P., Huntington, P., Fieldhouse, M., Gunter, B., Withey, R., Jamali, H., Dobrowolski, T., \& Tenopir, C. (2008). The Google generation: the information behaviour of the researcher of the future. Aslib Proceedings, 60 (4), 290-310. Retrieved September 02, 2017, from https://doi.org/10.1108/00012530810887953.

Schiefele, U. (1991). Interest, learning, and motivation. Educational Psychologist, 26, 299-323.

Schreiner, C., Sjøberg, S. (2004). Sowing the seeds of ROSE. Background, rationale, questionnaire development and data collection for ROSE (The Relevance of Science Education) - A comparative study of students' views of science and science education. Acta Didactica, 4, 1-20.

Science Education in Europe: National Policies, Practices and Research (2011). Brussels: Education, Audiovisual and Culture Executive Agency, P9 Eurydice.

Uitto, A., Juuti, K., Lavonen, J., \& Meisalo, V. (2006). Students' Interest in Biology and Their Out-of-School Experiences. Journal of Biological Education, 40 (3), 124-129.

Watson, J. C. (2017). Establishing evidence for internal structure using exploratory factor analysis, 232-238. Retrieved November 02 , 2017, from https://doi.org/10.1080/07481756.2017.1336931

Žogla, I. (2001). Didaktikas teorētiskie pamati [Theoretical basis of didactics]. Rīga: Raka, 46. (In Latvian) 


\section{Appendix}

\section{Factor analysis excluded items}

(load values from 0.40 to 0.60 )

\begin{tabular}{|c|c|c|c|c|c|c|}
\hline \multirow{2}{*}{ Items } & \multirow{2}{*}{$\mathbf{M}$} & \multirow{2}{*}{ SD } & \multicolumn{4}{|c|}{ Rotated factor load values } \\
\hline & & & Factor 1 & Factor 2 & Factor 3 & Factor 4 \\
\hline B4 & 3.13 & 1.00 & .56 & & & \\
\hline B7 & 2.20 & 1.12 & .55 & & & \\
\hline $\mathrm{B} 1$ & 2.40 & 1.24 & .51 & & & \\
\hline B6 & 2.66 & 1.15 & .51 & & & \\
\hline $\mathrm{B} 12$ & 2.56 & 1.13 & .50 & & & \\
\hline B15 & 3.03 & 1.06 & .40 & & & \\
\hline $\mathrm{A} 12$ & 2.54 & 1.09 & & .48 & & \\
\hline B5 & 2.75 & 1.13 & & .42 & & \\
\hline A13 & 2.83 & .87 & & & .59 & \\
\hline A9 & 2.31 & 1.04 & & & & .54 \\
\hline $\mathrm{A} 10$ & 2.79 & .98 & & & & .47 \\
\hline
\end{tabular}

\begin{tabular}{|cl|}
\hline $\begin{array}{r}\text { Dagnija Cēdere } \\
\text { (Corresponding author) }\end{array}$ & $\begin{array}{l}\text { Dr.chem., Associate Professor, University of Latvia, Jelgavas street } \\
\text { 1, LV-1004, Riga, Latvia. } \\
\end{array}$ \\
E-mail: dagnija.cedere@lu.Iv \\
\hline Inese Jurgena & Dr.paed., Professor, University of Latvia, Imantas linija 7/1, LV- \\
& 1083, Riga, Latvia. \\
& E-mail: inese.jurgena@lu.lv \\
\hline Vilija Targamadze & Dr.phil., Prof. habil., Vilnius University, Universiteto street 9/1, LT- \\
& 01513, Vilnius, Lithuania. \\
& E-mail: vilija.targamadze@gmail.com \\
\hline
\end{tabular}

